\title{
A Repercussão do Fenômeno das Falsas Memórias na Prova Testemunhal: uma análise a partir dos Julgados do Tribunal de Justiça do Rio Grande do Sul
}

\author{
The Repercussion of the False Memories Syndrome in \\ the Eyewitness Testimony: an Analysis of Decisions \\ from the Rio Grande do Sul State Court
}

\author{
Flaviane Baldasso $^{1}$ \\ Universidade do Vale do Rio dos Sinos - São Leopoldo/RS \\ flavibaldasso@gmail.com \\ http://lattes.cnpq.br/8552018755566744 \\ http://orcid.org/0000-0002-8375-8380 \\ Gustavo Noronha de Ávila ${ }^{2}$ \\ Centro de Ensino Superior de Maringá - Maringá/PR \\ gustavonoronhadeavila@gmail.com \\ http://lattes.cnpq.br/4220998164028087 \\ https://orcid.org/0000-0002-7239-1456
}

Resumo: As falsas memórias são distorções da memória que podem impactar determinantemente na avaliação de um evento criminoso de interesse do sistema penal. Apesar do crescente interesse pelo tema, poucos trabalhos empíricos têm explorado as consequências práticas do fenômeno. A par disso, questiona-se se é possível medir a sua repercussão para o nosso processo penal, bem como se as teses referentes às falsas memórias têm sido aceitas pelo Poder Judiciário e em quais casos. O presente artigo pretende analisar a repercussão do fenômeno das

1 Bacharel em Direito e Especialista em Direito Penal e Processo Penal pela UNISINOS. Advogada.

2 Doutor e Mestre em Ciências Criminais pela PUCRS. Professor do Mestrado em Ciências Jurídicas e da Graduação em Direito do Unicesumar. Bolsista Produtividade do ICETi. 
falsas memórias, em matéria de prova testemunhal, a partir de 437 acórdãos do Tribunal de Justiça do Rio Grande do Sul. Utilizando a metodologia da análise de conteúdo de Lawrence Bardin, foram explorados os tipos de crimes nos quais o argumento das falsas memórias tem sido utilizado, se a hipótese de ocorrência dessa distorção tem sensibilizado os julgadores, bem como se as análises dos julgadores têm se amparado na produção bibliográfica acerca da psicologia do testemunho. A partir dos números levantados foi possível perceber um incremento bastante acentuado na invocação do argumento das falsas memórias, porém sem que isto tenha sido revertido na promoção de liberdade no âmbito do processo penal gaúcho.

Palavras-chave: prova testemunhal; psicologia do testemunho; falsas memórias.

ABSTRACT: False memories are distortions of memory that can impact decisively on the evaluation of a criminal event of interest to the criminal system. Despite the growing interest in the subject, few empirical works have explored the practical consequences of the phenomenon. Along with, the question is if it is possible to measure the repercussion for our criminal proceedings, as well if the theses concerning false memories have been accepted by the Judiciary and in which cases. The present article intends to analyze the repercussion of the phenomenon of false memories, in terms of testimonial evidence, from 437 judgments of the Court of Justice of Rio Grande do Sul. Using the content analysis methodology of Lawrence Bardin, we explored the types of crimes in which the false memories argument has been used, if the hypothesis of this distortion has sensitized the judges, as well as if the analyzes of the judges have been supported in the bibliographical production on the psychology of the testimony. From the numbers raised, it was possible to perceive a considerable increase in the invocation of the argument of the False Memories, but this has not been reversed in the promotion of freedom in the scope of the gaucho penal process.

KeYwords: testimonial evidence; psychology of testimony; false memories.

\section{INTRODUÇÃO}

O fenômeno das falsas memórias não é novo. Porém, mesmo com a persistente desconfiança acerca da credibilidade das provas penais dependentes da memória, especialmente o testemunho, remontar 
a séculos atrás ${ }^{3}$, os estudos experimentais da psicologia do testemunho são relativamente recentes ${ }^{4}$.

Falsas memórias são lembranças de um evento que não ocorreu ou, caso tenha acontecido, se desenrolou de forma diferente da lembrada pela testemunha ou vítima ${ }^{5}$. Desde os estudos pioneiros no Brasil acerca do tema, o debate tem sido objeto de crescente interesse da comunidade jurídica. Exemplo disto foi o Diagnóstico Nacional de Práticas de Entrevistas Forenses e Reconhecimento Pessoal, financiado pelo Ministério da Justiça ${ }^{6}$. Foi justamente a preocupação acerca da (má)

3 FARINACCI, Prosperi. Tractatus Integer de Testibus (1617). Disponível em: <http://reader.digitale-sammlungen.de/en/fs1/object/display/bsb106 25696_00001.html>. Acesso em: 15 nov. 2017.

4 LOFTUS, Elizabeth; PALMER, J.C. Reconstruction of automobile destruction: An example of the interaction between language and memory. Journal of Verbal Learning \& Verbal Behavior, 13(5), 1974, p. 585-589.

5 STEIN, Lilian Milnitsky; NEUFELD, Carmem Beatriz. Falsas Memórias: Porque Lembramos de Coisas que não Aconteceram? Arquivos de Ciências da Saúde da UNIPAR, vol. 5, n. 2, p. 179-186, 2001. O fenômeno das falsas memórias pode ser compreendido como um processo mnemônico composto "[...] no todo ou em parte por lembranças de informações ou eventos que não ocorreram na realidade". Não são mentiras ou fantasias dos indivíduos, são lembranças semelhantes às memórias verdadeiras. Além disso, as falsas memórias são fruto do funcionamento normal da memória humana, e não patológico. Essas distorções podem ser tanto de cunho interno quanto externo à pessoa. Quando se tratam de distorções endógenas, as falsas memórias são denominadas autossugeridas, ocorrendo quando a lembrança é alterada internamente pelo indivíduo, fruto do próprio funcionamento da memória, sem a interferência de uma fonte externa. Por exemplo, lembrar que um amigo contou uma história quando, na verdade, as informações são provenientes de um programa de televisão. Por outro lado, quando se tratam de distorções exógenas, as falsas memórias são denominadas sugeridas, por sua vez, são resultado de um processo de interferência externo ao sujeito, por uma fonte alheia à pessoa. Neste tipo de falsificação da memória, há uma recordação de fatos como se tivessem sido realmente vividos, quando, na verdade, foram sugeridos. Por exemplo, recordar de um fato pela sugestionabilidade do entrevistador. Sobre isso: NEUFEULD, Carmem; BRUST, Priscila Goergen; STEIN, Lilian Milnitsky. Compreendendo o fenômeno das falsas memórias. In: STEIN, Lilian Milnitsky et al. Falsas memórias: fundamentos científicos e suas aplicações clínicas e jurídicas. Porto Alegre: Artmed, 2010. p. 22-26.

6 STEIN, Lilian Milnitsky; ÁVILA, Gustavo Noronha de et al. Avanços científicos em psicologia do testemunho aplicados ao reconhecimento pessoal e aos 
utilização daquelas provas que proporcionou linha de financiamento para a realização de investigação científica.

Por outro lado, mesmo sendo tema de crescente atenção, é possível medir a sua repercussão para o nosso processo penal? As teses referentes às falsas memórias têm sido aceitas pelo Poder Judiciário? Em quais casos?

Tendo em mente estas questões, foram levantados 437 acórdãos do Tribunal de Justiça do Estado do Rio Grande do Sul (TJRS), onde o tema foi mencionado, no período entre 23 de setembro de 2004 e 23 de junho de 2017. Após a delimitação da amostra, os resultados foram submetidos à sistematização a partir da técnica da análise de conteúdo ${ }^{7}$.

Por sua fragilidade a prova penal dependente da memória deve estar cercada de todas as cautelas possíveis no momento de sua produção, bem como de sua avaliação. Isto é reforçado pelos resultados de recentes investigações empíricas, que demonstraram inaceitável distanciamento entre as práticas forenses e os saberes da psicologia do testemunho ${ }^{8}$.

\section{Contextualização Metodológica}

A prova testemunhal é o meio probatório mais utilizado na formação do convencimento do julgador no âmbito do processo penal. De outro lado, por depender tão somente da memória do indivíduo, também se pode dizer que é um dos meios probatórios mais frágeis, devido à sua exposição a diversos fatores de contaminação, sendo um deles as falsas memórias, sejam elas de origem endógena ou exógena?

depoimentos forenses. Brasília, DF, 2015. Disponível em: <http://pensando. mj.gov.br/wp-content/uploads/2016/02/PoD_59_Lilian_web-1.pdf >. Acesso em: 03 set. 2017.

7 Sobre isso, ver: BARDIN, Lawrence. Análise de conteúdo. Tradução Luis Antero Reto e Augusto Pinheiro. Lisboa: Edições 70, 1977.

8 STEIN, Lilian Milnitsky; ÁVILA, Gustavo Noronha de et al. Avanços científicos em psicologia do testemunho aplicados ao reconhecimento pessoal e aos depoimentos forenses. Brasília, DF, 2015. Disponível em: <http://pensando.mj. gov.br/wp-content/uploads/2016/02/PoD_59_Lilian_web-1.pdf >. Acesso em: 03 set. 2017.

9 Transportando as falsas memórias para dentro do processo penal, pode se ter a ocorrência de falsas memórias endógenas, em razão do tempo decorrido 
Não obstante a literatura nacional ${ }^{10}$, tanto da área da psicologia quanto da área jurídica, ter demonstrado profunda preocupação com o fenômeno das falsas memórias, diante da forte influência que exerce no resultado da ação penal e, consequentemente, na vida do acusado, ainda são poucas as pesquisas empíricas que abordam como esse processo mnemônico vem sendo percebido pela jurisprudência pátria e como tem repercutido nos julgados. Foi a partir dessa perspectiva que se delineou o presente estudo, buscando-se observar a repercussão das falsas memórias nos julgados do TJRS.

Optou-se por realizar a pesquisa empírica apenas no âmbito do TJRS, a um, pelo grande volume de julgados que resultaram da pesquisa preliminar (437 decisões), compreendendo material capaz de produzir novas informações; a dois, por ser o Rio Grande do Sul o estado natal dos autores, para poderem compreender melhor a realidade dos dados; a três, porque as pesquisas pioneiras sobre falsas memórias, no Brasil, são oriundas da PUCRS, pela coordenação da professora Lilian Milnitsky Stein, ademais de continuar sendo encontrada no Rio Grande do Sul a maior incidência de pesquisas na área da psicologia do testemunho. Há de se ressaltar que antes de ser escolhido definitivamente o tema da pesquisa empírica (a repercussão do fenômeno das falsas memórias no TJRS), foram realizadas consultas em outros Tribunais, contudo, nenhuma teve resultado tão expressivo quando o TJRS.

entre a data do fato e dos depoimentos na fase policial e judicial; e exógenas, podendo surgir de informações divulgadas pela mídia sobre as investigações e o andamento do processo ou pela postura e uso da linguagem de quem está tomando o depoimento da vítima ou da testemunha. Sobre isso: AQUINO, José Carlos G. Xavier de. A prova testemunhal no processo penal brasileiro. 4 ed. rev. e ampl. São Paulo: Juarez de Oliveira, 2002; ÁVILA, Gustavo Noronha de. Falsas Memórias e Sistema Penal. Rio de Janeiro: Lumen Juris, 2013; DI GESU, Cristina. Prova penal e falsas memórias. 2. ed. ampl. e rev. Porto Alegre: Livraria do Advogado, 2014; GAUER, Gustavo. Falsas memórias. In: OLIVEIRA, Alcyr Alves (Org.). Memória: cognição e comportamento. São Paulo: Casa do Psicólogo, 2007. Livro eletrônico. p. 165-183; LOPES JÚNIOR, Aury. Direito processual penal. 11. ed. São Paulo: Saraiva, 2014; STEIN, Lilian Milnitsk (Org.). Falsas memórias: fundamentos científicos e suas aplicações clínicas e jurídicas. Porto Alegre: Artmed, 2010; MORAIS DA ROSA, Alexandre. Guia Compacto do Processo Penal. $3^{\mathrm{a}}$ ed. Florianópolis: Empório do Direito, 2016. 
Assim, a pesquisa foi dividida em duas etapas, tendo a primeira servido de base para a segunda. Contemplando-se tanto abordagens quantitativas quanto qualitativas, foram empregados procedimentos de pesquisa documental e de levantamento de dados. O tratamento destes dados se deu sob a forma de cálculos percentuais e análise de conteúdo dos acórdãos, seguindo os critérios descritos por Lawrence Bardin ${ }^{11}$.

O método da análise de conteúdo foi utilizado na presente pesquisa, pois trabalha com um conjunto de normas flexíveis a serem seguidas, havendo a possibilidade de adaptação aos propósitos do estudo. Segundo Lawrence Bardin, “[...] é um método muito empírico, dependente do tipo de 'fala' a que se dedica e do tipo de interpretação que se pretende com o objetivo. Não existe o pronto-a-vestir [...], mas somente algumas regras de base, por vezes dificilmente transponíveis" ${ }^{2}$.

Essas regras de base organizam-se em três diferentes fases: a) pré-análise; b) a exploração do material; e c) o tratamento dos resultados, a inferência e a interpretação. Em síntese, a primeira fase tem por objetivo a organização dos documentos a serem analisados, a fim de torná-los operacionais e sistematizar as ideias iniciais. A segunda, da exploração do material, consiste na adoção de procedimentos manuais ou de operações a serem realizadas pelo pesquisador, tais como a enumeração dos documentos. Por fim, a terceira fase busca tratar os resultados brutos de maneira a torná-los significativos e válidos, permitindo-se estabelecer quadros que condensam e põem em relevo as informações fornecidas na análise. Aqui, aplicam-se operações estatísticas simples, como cálculos percentuais, a partir do tratamento dos dados em planilhas do software Microsoft Excel. O tratamento desses resultados pode, ainda, “[...] servir de base a uma outra análise disposta em torno de novas dimensões teóricas [...]"13.

Assim, funcionando segundo procedimentos sistemáticos e objetivos de descrição do conteúdo das mensagens, a análise de conteúdo trata as informações contidas na própria mensagem ${ }^{14}$. Logo, essa siste-

11 BARDIN, Lawrence. Análise de conteúdo. Tradução Luis Antero Reto e Augusto Pinheiro. Lisboa: Edições 70, 1977, p. 30-31.

12 Ibid., p. 30-31.

13 Ibid., p. 95-102.

14 Ibid., p. 34. 
matização tem se mostrado um importante norte a ser empregado tanto em análises quantitativas quanto qualitativas, tal como a abordagem que se busca contemplar neste trabalho.

A primeira etapa da pesquisa compreendeu uma investigação exploratória acerca da ocorrência da expressão "falsas memórias" nas decisões da Seção Crime do TJRS, a fim de nortear a coleta de dados para a análise pretendida na segunda etapa. Há de se dizer que o tratamento dos dados pela análise de conteúdo, neste primeiro momento de cunho quantitativo, se mostrou oportuno, na medida em que esse método “[...] enriquece a tentativa exploratória, aumenta a propensão à descoberta. É a análise de conteúdo "pra ver o que dá'"15.

Assim, escolhendo-se os acórdãos proferidos pelo Tribunal de Justiça do Rio Grande do Sul como os documentos a serem submetidos à análise, formularam-se as seguintes hipóteses a serem verificadas: a) quantas decisões resultariam da pesquisa empregando a palavra-chave "falsas memórias"; b) a partir de quando o tema começou a ser objeto de análise no Tribunal de Justiça; c) em que âmbito processual foi trazida a discussão; e d) qual o delito relacionado ao julgamento.

Para possibilitar a exploração dos acórdãos, utilizou-se o serviço de "Pesquisa de Jurisprudência" disponível no sítio do Tribunal de Justiça ${ }^{16}$. A consulta ocorreu da seguinte forma: no canto esquerdo da página inicial do sítio é possível acessar o link "Jurisprudência”, que amplia o catálogo de opções dos serviços, contemplando a alternativa de "Pesquisa de Jurisprudência”. Clicando-se nesse sublink, o sítio redireciona para a página de pesquisa, contando com a possibilidade de seleção de diversos filtros.

Primeiramente, optou-se por pesquisar utilizando a expressão "falsas memórias", com o índice "Ementa”, aplicando os filtros "Tribunal de Justiça do RS" e "Seção Crime", limitando-se apenas o termo final da "Data de Julgamento" para 25 de junho de 2017 - data da realização da pesquisa. O resultado gerou uma lista de 28 (vinte e oito) acórdãos, todos proferidos em sede de Apelação Crime, classificados por data decrescente, sendo o julgado mais recente datado de 19 de junho de 2017 e o mais antigo de 25 de outubro de 2007.

15 BARDIN, Lawrence. Análise de conteúdo. Tradução Luis Antero Reto e Augusto Pinheiro. Lisboa: Edições 70, 1977, p. 30.

16 RIO GRANDE DO SUL. Tribunal de Justiça. Porto Alegre, 2017. Disponível em: <http://www.tjrs.jus.br/ site/>. Acesso em 27 set. 2017. 
Contudo, considerando ser reduzido o número de acórdãos encontrados, ampliou-se a busca para o índice de "Inteiro Teor" dos julgados, recaindo o critério de busca sobre o conteúdo dos documentos dos acórdãos, mantendo-se os demais filtros - Tribunal de Justiça do RS, Seção Crime e Data de Julgamento até 25 de junho de 2017. A consulta resultou, então, em 437 acórdãos.

Enumerados esses acórdãos através da própria estrutura de filtros disponível na Pesquisa de Jurisprudência, passou-se a efetuar o tratamento dos resultados através de operações estatísticas, de maneira a torná-los significativos e válidos diante do propósito deste trabalho. Tendo à disposição esses mecanismos, foi possível condensar as informações em gráficos e tabelas a seguir expostos.

\section{Descrição dos Resultados}

O resultado da busca gerou uma lista de 437 acórdãos para "falsas memórias”, que foram analisados de forma quantitativa, aferindo-se a ocorrência da palavra-chave mediante a categorização apresentada a seguir.

No total dos acórdãos listados, o julgado mais antigo data de 23 de setembro de 2004, enquanto o mais recente data de 23 de junho de 2017; ambos referem-se a decisões proferidas em sede de Apelação Crime. Vê-se, portanto, que o tema tem sido suscitado nos acórdãos criminais há aproximadamente 13 anos, coadunando-se a abordagem jurisprudencial com o início das pesquisas sobre o falseamento da memória realizadas no Brasil, que possuem marco inicial no início da década de $2000^{17}$.

Observou-se, ainda, uma crescente produção no número de acórdãos que mencionam a expressão "falsas memórias" no período pesquisado, saindo de 01 decisão em 2004 para 82 em 2017 (Gráfico 1). A produção de acórdãos para o período dos sete últimos anos - 2011 a 2017 - foi quinze vezes maior do que a produção para o período dos sete primeiros anos - 2004 a 2010, representando este $6,18 \%$ do total das decisões listadas, enquanto aquele representou $93,83 \%$.

17 Sobre isso: STEIN, Lilian Milnitsky; NEUFELD, Carmem Beatriz. Falsas Memórias: Porque Lembramos de Coisas que não Aconteceram? Arquivos de Ciências da Saúde da UNIPAR, vol. 5, n. 2, p. 179-186, 2001. 
GRÁfICo 1 - Produção de Acórdãos no Período da Pesquisa

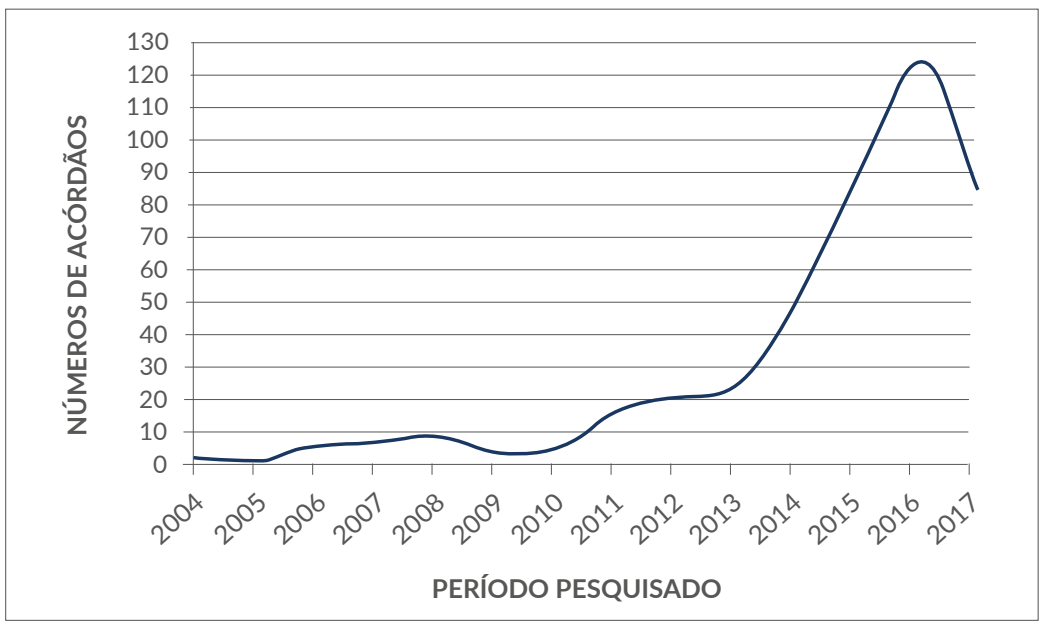

Fonte: Os autores.

No que diz respeito ao âmbito processual, pela classificação “Tipo de Processo" empregada pelo próprio Tribunal Gaúcho, a maior ocorrência do termo "falsas memórias" se deu em acórdãos de Apelação Crime (90,16\%), encontrando-se, também, em Embargos de Declaração (2,52\%); Embargos Infringentes e de Nulidade (2,29\%); Habeas Corpus (1,60\%); Recurso em Sentido Estrito (1,14\%); Revisão Criminal (1,14\%); e Recurso Especial e/ou Extraordinário (1,14\%). A Tabela 1 apresenta a referida proporção.

TABeLA 1 - Relação de Decisões por Âmbito Processual

\begin{tabular}{c|c|c|}
\hline Tipo de Processo & $\mathbf{N}^{\mathbf{0}}$ de Decisões & Percentual \\
Apelação Crime & 394 & $90,16 \%$ \\
Embargos de Declaração & 11 & $2,52 \%$ \\
\hline Embargos Infringentes e de Nulidade & 10 & $2,29 \%$ \\
\hline Habeas Corpus & 7 & $1,60 \%$ \\
\hline
\end{tabular}




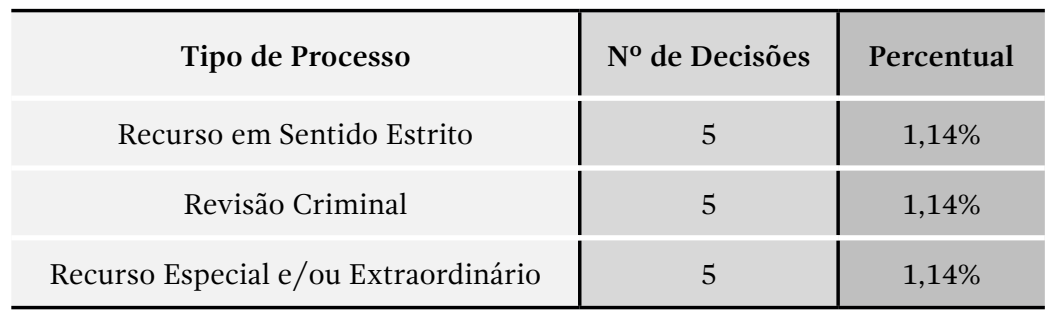

Fonte: Os autores.

Considerando o delito relacionado ao julgamento que traz a expressão "falsas memórias", segundo a classificação "Assunto CNJ", a pesquisa apontou diversos tipos penais, sendo os mais frequentes os crimes de: estupro de vulnerável $(47,14 \%)$; roubo majorado $(17,39 \%)$; atentado violento ao pudor $(15,10 \%)$ e estupro $(5,95 \%)$. Ademais, os crimes contra a dignidade sexual representam $68,88 \%$; os crimes contra o patrimônio $23,11 \%$; os crimes contra a vida $1,14 \%$; os crimes previstos em leis especiais 1,60\%; e os acórdãos sem classificação do tipo penal 5,26\%. A aludida relação está representada pelo Gráfico 2 e pela Tabela 2 .

GRÁfICo 2 - Relação de Decisões por Natureza Jurídica do Crime

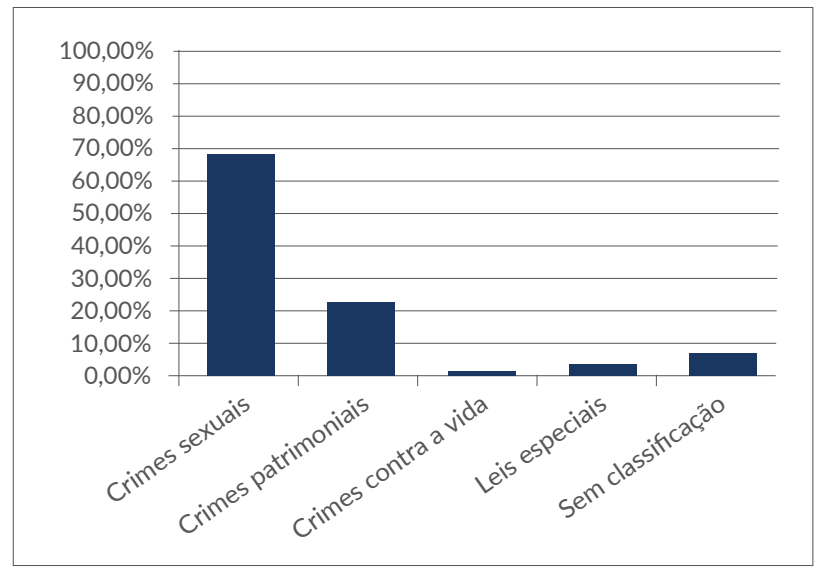

Fonte: Os autores. 
TABela 1 - Relação de Decisões por Tipo Penal

\begin{tabular}{|c|c|c|}
\hline Tipo Penal & $N^{o}$ de Decisões & Percentual \\
\hline Estupro de vulnerável & 206 & $47,14 \%$ \\
\hline Roubo majorado & 76 & $17,39 \%$ \\
\hline Atentado violento ao pudor & 66 & $15,10 \%$ \\
\hline Estupro & 26 & $5,95 \%$ \\
\hline Sem classificação & 23 & $5,26 \%$ \\
\hline Roubo & 10 & $2,29 \%$ \\
\hline Latrocínio & 5 & $1,14 \%$ \\
\hline Furto & 4 & $0,92 \%$ \\
\hline Homicídio qualificado & 4 & $0,92 \%$ \\
\hline Tráfico de drogas e condutas afins & 4 & $0,92 \%$ \\
\hline Furto qualificado & 3 & $0,69 \%$ \\
\hline Extorsão mediante sequestro & 2 & $0,46 \%$ \\
\hline $\begin{array}{c}\text { Satisfação de lascívia mediante presença de } \\
\text { criança ou adolescente }\end{array}$ & 2 & $0,46 \%$ \\
\hline Crimes de tortura & 1 & $0,23 \%$ \\
\hline $\begin{array}{c}\text { Crimes previstos no Estatuto da Criança } \\
\text { e do Adolescente }\end{array}$ & 1 & $0,23 \%$ \\
\hline Decorrente de violência doméstica & 1 & $0,23 \%$ \\
\hline Estelionato & 1 & $0,23 \%$ \\
\hline $\begin{array}{l}\text { Favorecimento da prostituição ou outra } \\
\text { forma de exploração sexual de vulnerável }\end{array}$ & 1 & $0,23 \%$ \\
\hline Homicídio simples & 1 & $0,23 \%$ \\
\hline
\end{tabular}

Fonte: Os autores 
Em síntese, este primeiro momento revelou-se fundamental para aproximação com o objeto da pesquisa. O número de 437 decisões que derivaram da consulta e a crescente produção de acórdãos que suscitaram a expressão "falsas memórias" nos últimos sete anos surpreenderam diante dos resultados que eram esperados pelos pesquisadores ao idealizar o projeto.

A partir dos resultados obtidos, avaliou-se ser necessário incluir na fase seguinte os julgados proferidos em sede de Recurso em Sentido Estrito, e não apenas de Apelações Criminais como inicialmente pensouse o estudo.

Assim, as informações exploradas apontaram que a discussão do fenômeno das falsas memórias não é tão incomum na jurisprudência do TJRS como se pensava e vem sendo trazido ao debate há mais de dez anos. Ademais, embora tenha sido inicialmente tímida, a incidência do tema nos julgados está ascendendo no Estado, o que pode demonstrar um possível aumento na familiaridade e, porque não, na preocupação dos atores judiciais com a psicologia do testemunho e a sua influência no deslinde processual.

Por fim, os dados revelaram ocorrer nos crimes sexuais a maior frequência da problemática, os quais são geralmente cometidos às escondidas e, na maioria das vezes, possíveis de serem esclarecidos tão somente com a prova oral.

A segunda etapa da pesquisa teve como objetivo observar como o fenômeno das falsas memórias sobre a prova oral - palavra da vítima e testemunho - tem sido percebido nos julgamentos de Recursos de Apelação e Recursos em Sentido Estrito pelo TJRS. Cumpre referir que as informações aqui trabalhadas tiveram por base os resultados da análise de conteúdo efetuada no tópico anterior. A Tabela 3 representa a primeira categorização dos acórdãos.

TABeLA 2 - Relação de Decisões por Âmbito Processual

\begin{tabular}{c|c}
\hline Tipo de Processo & No de Decisões $^{\circ}$ \\
Apelação Crime & 394 \\
Recurso em Sentido Estrito & 5 \\
\hline
\end{tabular}

Fonte: Os autores. 
A partir dos dados obtidos pela pesquisa exploratória, foram separadas, inicialmente, as 41 decisões mais antigas das 394 listadas na busca por Apelação Crime, restando compreendidas todas aquelas proferidas no período de setembro de 2004 a novembro de 2011. Foram escolhidos os 41 julgados mais antigos, pois desde o primeiro contato com os acórdãos se buscou empregar critérios objetivos de seleção para futura análise de conteúdo, a fim de evitar eventuais tendências pessoais na sua escolha. Verificou-se que essas decisões compreendiam a discussão da prática de diversificados tipos penais (estupro, atentado violento ao pudor, roubo simples e majorado, tráfico de drogas). Além disso, representaram também uma amostra da crescente produção de acórdão, começando com 1 julgado em 2004 chegando até 15 julgados em 2011. Como o objetivo não era esgotar a leitura de acórdãos, mas sim criar uma aproximação com as decisões judiciais que tratavam do tema das falsas memórias, entendeu-se ser suficiente a leitura desses julgados. Em seguida, foram lidos em profundidade os julgados ${ }^{18}$, a fim de tomar-se contato com o seu conteúdo.

Não se descartando a possibilidade de novas inclusões, foram definidas, a princípio, os seguintes problemas: a) qual o contexto em que a expressão "falsas memórias" foi trazida; b) que meio probatório teve sua credibilidade analisada, se a palavra do ofendido ou o testemunho; c) houve o emprego de alguma técnica de entrevista para a tomada das declarações; d) foi reconhecida a ocorrência de falsas memórias; e) acaso reconhecida a presença das falsas memórias, qual o fator de contaminação foi apontado; f) se o meio probatório questionado constituiu-se em elemento de convicção do julgador; g) como foi a abordagem da fundamentação da decisão sobre o assunto; e h) qual o resultado do processo.

De pronto, dessa prévia leitura, entendeu-se por necessário ampliar o campo de abordagem da pesquisa para incluir a prova decorrente também da palavra de crianças e adolescentes, acrescentando-se aos problemas de estudo a idade dos declarantes. Embora o foco do presente trabalho seja a criação de falsas memórias em testemunhas adultas,

18 Lawrence Bardin denomina esta etapa da pesquisa de leitura flutuante, que consiste na atividade de estabelecer contato com os documentos a serem analisados e de conhecer o texto a fim de retirar impressões e orientações para as etapas seguintes (BARDIN, Lawrence. Análise de conteúdo. Tradução Luis Antero Reto e Augusto Pinheiro. Lisboa: Edições 70, 1977. p. 96). 
mostrou-se ser essencial a inclusão daqueles acórdãos que tratavam do falseamento da memória em menores de idade à efetiva análise da percepção e repercussão do fenômeno estudado na jurisprudência. Ademais, o reduzido (quase nulo) número de decisões que, nesse primeiro momento, aportaram o debate sobre o testemunho de pessoa maior de idade implicaria em poucos recursos para a pesquisa.

Ainda, observou-se ser importante abarcar nas questões de estudo a análise quanto à realização de prova pericial destinada a constatar a produção de falsas memórias nos casos concretos, haja vista terem sido encontrados diversos acórdãos que traziam essa informação. Esse dado igualmente se revela significativo na compreensão de como o fenômeno do falseamento da memória tem sido percebido no âmbito jurisprudencial.

Ademais, ao final desse primeiro e breve contato, avaliou-se ser suficiente a retirada de uma amostra das decisões para um exame mais acurado, através de escolha aleatória, estabelecendo-se, diante do volume de acórdãos listados, um percentual mínimo de $20 \%$ sobre as decisões proferidas em cada âmbito processual ${ }^{19}$. Foi selecionada uma amostra de $20 \%$ das decisões relacionadas a cada tipo penal, pois diante do grande número de decisões que resultaram da consulta (399, das quais 394 apelações e 5 RSE), este percentual resultaria em, aproximadamente, 80 decisões. Entendeu-se ser suficiente este número para se traçar tanto um estudo quantitativo, como qualitativo da repercussão das falsas memórias no TJRS. Ademais, a retirada de amostra para a análise qualitativa encontra guarida na metodologia da análise de conteúdo de Lawrence Bardin.

Aquelas decisões oriundas do julgamento de apelações criminais foram, ainda, sorteadas dentro de cada tipo penal relacionado de acordo com o filtro "Assunto CNJ" (Tabela 4). Já aquelas oriundas do julgamento de Recurso em Sentido Estrito foram escolhidas sobre o total do resultado, a um porque contemplam apenas 5 decisões; a dois porque, estão relacionadas ao tipo penal de homicídio simples e qualificado (Tabela 5).

Optou-se por um percentual mínimo não absoluto, pois, como se vê da Tabela 4, para alguns delitos resultaram poucos acórdãos, tais como: furto (4) e furto qualificado (2); tráfico de drogas (3); extorsão mediante

19 Conforme Tabela 4, foram listados 394 acórdãos proferidos em sede de Apelação Crime; 5 em sede de Recurso em Sentido Estrito; e 5 em sede de Revisão Criminal. 
sequestro (2); satisfação de lascívia mediante presença de criança ou adolescente (2); crime de tortura (1); crime previsto no ECA (1); crime decorrente de violência doméstica (1); estelionato (1); e favorecimento da prostituição ou outra forma de exploração sexual de vulnerável (1). Nesses casos, foi analisada ao menos uma decisão sobre cada tipo penal relacionado, resultando num percentual maior de $20 \%$.

TABELA 3 - Relação de Delitos Abordados em Apelações

\begin{tabular}{|c|c|}
\hline Tipo Penal & $\mathrm{N}^{\mathrm{o}}$ de Decisões \\
\hline Estupro de vulnerável & 185 \\
\hline Roubo majorado & 74 \\
\hline Atentado violento ao pudor & 55 \\
\hline Sem classificação & 22 \\
\hline Estupro & 24 \\
\hline Roubo & 10 \\
\hline Latrocínio & 5 \\
\hline Furto & 4 \\
\hline Tráfico de drogas e condutas afins & 3 \\
\hline Furto qualificado & 3 \\
\hline Extorsão mediante sequestro & 2 \\
\hline $\begin{array}{l}\text { Satisfação de lascívia mediante presença } \\
\text { de criança ou adolescente }\end{array}$ & 2 \\
\hline Crimes de tortura & 1 \\
\hline $\begin{array}{c}\text { Crimes previstos no Estatuto da Criança } \\
\text { e do Adolescente }\end{array}$ & 1 \\
\hline Decorrente de violência doméstica & 1 \\
\hline Estelionato & 1 \\
\hline $\begin{array}{l}\text { Favorecimento da prostituição ou outra forma } \\
\text { de exploração sexual de vulnerável }\end{array}$ & 1 \\
\hline
\end{tabular}

Fonte: Os autores. 
TABELA 4 - Relação de Delitos Abordados em Recurso em Sentido Estrito

\begin{tabular}{c|c} 
Tipo Penal & No de Decisões $^{\circ}$ \\
Homicídio qualificado & 3 \\
Homicídio simples & 1 \\
Sem classificação & 1 \\
\hline
\end{tabular}

Fonte: Os autores.

Desse modo, chegou-se ao total de 82 decisões judiciais, sendo 81 oriundas de Apelações Criminais e 01 de Recurso em Sentido Estrito. Para a escolha aleatória, foi utilizado o serviço de sorteio "Gerador de Sequência Aleatória" disponibilizado gratuitamente em Random.org ${ }^{20}$.

Do total de acórdãos analisados (82), alguns não apresentaram dados claros relacionados ao foco do estudo, embora tenham dado entrada sob a temática das falsas memórias. Esses acórdãos apareceram nos resultados da busca por conterem uma ementa (5), ou a transcrição de depoimentos (2), ou a citação de uma obra (2) com o uso da expressão falsas memórias. Ainda, 18 decisões tratavam da ocorrência de falsas memórias no ato de reconhecimento dos acusados, relacionados predominantemente a delitos contra o patrimônio. Esses julgados (27) serão utilizados para pesquisas futuras.

De outro lado, os acórdãos que trouxeram a palavra-chave no voto propriamente dito (30), na síntese da tese defensiva exposta no Relatório do acórdão (11), nas transcrições de perícias psicológicas/psiquiátricas adotadas como razões de decidir (14) foram examinados mais detidamente. Assim, ao final da leitura chegou-se a um total de 55 decisões judiciais que contemplavam o objeto de pesquisa. A partir desse ponto foi necessário fazer uma leitura acurada dos acórdãos, extraindo-se deles os dados para análise.

\subsubsection{ANÁlISE DOS RESULtAdos}

Acreditamos que o importante incremento no número de citações do tema, entre 2013 e 2016, tenha sido causado por alguns importantes

20 RANDOM.ORG. Randomness and Integrity Services Ltd. Dublin, Irlanda, 1998. Disponível em: <https://www.random.org/sequences/>. Acesso em: 30 set. 2017. Tradução livre para Random Integer Generator. 
fatores. Primeiro, houve movimento importante da Defensoria Pública do Estado do Rio Grande do Sul em capacitar seus defensores para trabalhar com o tema das falsas memórias.

Isso porque, em uma das decisões que foram analisadas, proferida em 2017, pela $7^{\text {a }}$ Câmara Criminal (Apelação Crime $n^{0} 70073710907$ ), deparou-se com a referência à utilização da tese de falsas memórias pela Defesa, conforme se extrai de trecho da decisão que ora se colaciona: "Além disso, não se cogita da tese de "falsas memórias" que vem sendo inadequadamente empregada pela defesa pública [...]”. Ademais, o que se verificou é que a maior produção de julgados que abordou o tema era oriunda da $5^{\mathrm{a}}, 6^{\mathrm{a}}, 7^{\mathrm{a}}$ e $8^{\mathrm{a}}$ Câmara, cuja competência é julgar crimes contra a dignidade sexual e contra o patrimônio, ademais de crimes de trânsito e demais infrações penais.

Não se pode afirmar, pelos dados coletados - até mesmo porque a identificação do julgador não foi incluída nas hipóteses da pesquisa -, que o crescimento esteja relacionado à construção de algum desembargador em especial. Ainda, outra hipótese a ser aventada para o incremento é que o período também coincide com o lançamento de três trabalhos específicos sobre o assunto ${ }^{21}$.

Conforme exposto anteriormente, foram analisados 55 acórdãos proferidos em sede de Apelação Criminal (54) e Recurso em Sentido Estrito (1) que trataram sobre o tema das falsas memórias. Os resultados dessa análise serão ilustrados através de dados quantitativos e fragmentos representativos das decisões.

Inicialmente, quanto ao meio probatório sobre o qual foi suscitada a ocorrência de falsas memórias, $94,55 \%$, ou seja, 52 casos trataram da temática sobre a palavra da vítima, enquanto apenas 5,45\%, ou seja, 03 casos diziam respeito ao testemunho. Esses dados indicam, de pronto, que, não obstante o tema esteja ganhando espaço pela crescente de decisões que resultaram nos últimos 07 anos, conforme visto por ocasião da primeira etapa da pesquisa abordada no tópico anterior, o foco está direcionado à

21 Falamos de STEIN, Lilian M. (Org.). Falsas Memórias. Porto Alegre: Artmed, 2010; DI GESU, Cristina de. Prova Penal e Falsas Memórias. Rio de Janeiro: Lumen Juris, 2010; ÁVILA, Gustavo Noronha de. Falsas Memórias e Sistema Penal. Rio de Janeiro: Lumen Juris, 2013. 
palavra da vítima. Vê-se que o debate sobre as falsas memórias quando se trata de prova testemunhal ainda é pouco recorrente.

No que tange à classificação pela idade da pessoa que teve a credibilidade do relato questionado, foram divididos em três grupos: criança - até doze anos -, adolescente - de doze a dezoito anos - e adulto - acima de 18 anos. Obteve-se o seguinte quadro: em 43 acórdãos $(78,18 \%)$ traziam ao debate a criação de falsas memórias em crianças; 04 em adolescentes (7,27\%); e 08 em adultos (14,55\%).

No que se refere à técnica empregada na entrevista judicial, em apenas $18,18 \%$ dos casos adotou-se um método especial de oitiva, o qual consistia no Sistema do Depoimento Sem Dano ou Depoimento Especial ${ }^{22}$. Disso, observou-se que todos os processos em que a referida técnica foi empregada estavam relacionados a delitos contra a dignidade sexual de crianças e adolescentes. Por outro lado, em $80 \%$ dos casos não foi - ou, ao menos, não se pode depreender que tenha sido - aplicada técnica especial de oitiva, mesmo se tratando de testemunho infantil; em 1,82\% sequer houve a entrevista judicializada.

Nesse ponto, pode-se observar em alguns julgados que já há uma preocupação quanto ao tipo de pergunta formulado durante a entrevista da vítima ou da testemunha, encontrando-se importantes considerações

22 Idealizado pelo magistrado José Antônio Daltoé Cezar e implantado como Projeto-piloto em 2003 no $2^{\circ}$ Juizado da Infância e Juventude do Foro Central da Comarca de Porto Alegre, consiste em um método especial de tomada de depoimento de crianças e adolescentes vítimas e/ou testemunhas de violência. A metodologia do Depoimento Especial permite retirar de dentro da sala de audiências tradicional, que é um espaço formal, a criança ou adolescente vítima de violência, que necessite ser ouvida em juízo. Assim, em uma sala especial, mais acolhedora e garantindo a segurança da criança ou adolescente, será realizada uma escuta protegida, menos invasiva, preservando, desta forma, sua dignidade. Na sala especial, permanecerá somente a criança ou adolescente vítima/testemunha e o entrevistador, que poderá ser um assistente social ou um psicólogo. Este profissional deverá ser capacitado em entrevista forense com crianças e adolescentes, possibilitando o relato livre e adequando as perguntas à linguagem infanto-juvenil. O Depoimento Especial contribui também para a redução do número de oitivas de crianças ou adolescentes, pois sendo a entrevista gravada em vídeo, a mídia será anexada ao processo, evitando, desse modo, a repetição de depoimentos dentro do Sistema de Justiça (RIO GRANDE DO SUL. Tribunal de Justiça. Depoimento especial. Porto Alegre, 2017. Disponível em: <http://jij.tjrs.jus.br/depoimento-especial>. Acesso em: 21 out. 2017). 
acerca de realização de perguntas abertas ou fechadas ${ }^{23}$. É o que se extrai da Apelação Crime $\mathrm{n}^{0}$ 70051100709, da Terceira Câmara Criminal, cujo trecho ora se colaciona:

Após oito meses, a menina é ouvida em juízo (28/06/2011). Observo, da transcrição, que foi questionada com perguntas fechadas e sugestivas, que apresentam uma informação e eliciam resposta do tipo sim e não. Trata-se, com a devida vênia, de maneira menos adequada para retirar o máximo de informação acurada, óbice metodológico na técnica de entrevista para o qual os operadores do direito em geral, e o Poder Judiciário em particular, precisam atentar. Além da qualidade das perguntas, verifica-se que o pretor-entrevistador apresenta várias perguntas numa única formulação, aspecto que dificulta a compreensão por parte da interrogada, ainda mais quando se trata de uma criança tão pequena.

Oito meses é um grande lapso de tempo para uma criança desta idade, cujo processamento de memória ainda é predominantemente literal e, deste modo, os traços de memória são mais rapidamente perdidos com o tempo. Oito meses corresponde a um quinto da vida de uma criança de três anos e nove meses. As repostas de crianças pequenas - pré-escolares - a perguntas fechadas têm pouco valor do ponto de vista da precisão da memória, pois esta faixa etária é especialmente suscetível à aceitação de sugestões através deste tipo de perguntas. Assim, o fato da criança, em juízo, após oito meses, ter negado que o 'titio' tenha lhe batido de chinelo não tem valor no que tange à fidedignidade da memória, bem como não teria se ela tivesse respondido sim (pois foi uma reposta a uma pergunta fechada). De modo inverso, nota-se que quando a criança, em juízo, responde a perguntas abertas e menos sugestivas ('Alguma vez ele já te deu com alguma coisa assim?'; 'Conta pro tio o que aconteceu com vocês...'), espontaneamente relata que foi agredida com um tênis, que saiu sangue do nariz ${ }^{24}$. (grifo do autor).

23 De acordo com os estudos da Psicologia do Testemunho, as perguntas fechadas são as mais sugestionáveis possíveis. A sugestão externa como, por exemplo, de um entrevistador (escrivão, juiz, partes) será uma das principais fontes geradoras de Falsas Memórias. Sobre isso, ver: STEIN, Lilian Milnitsky; NEUFELD, Carmem Beatriz. Falsas Memórias: Porque Lembramos de Coisas que não Aconteceram? Arquivos de Ciências da Saúde da UNIPAR, vol. 5, n. 2, p. 179-186, 2001. RIO GRANDE DO SUL. Tribunal de Justiça. Apelação Crime $N^{o} 70051100709$, da $3^{\mathrm{a}}$ Câmara Criminal. Apelante: Ministério Público. Apelado: A.G.O. Relator: Des. Jayme Weingartner Neto. Porto Alegre, 06 de dezembro de 2012. 
Embora a questão tenha sido trazida no âmbito do testemunho infantil, o testemunho adulto também pode ser sugestionado pelo emprego de perguntas fechadas. Inclusive, a técnica da entrevista cognitiva determina que se inicie o questionamento com perguntas abertas para possibilitar o relato livre.

Em sentido semelhante, ainda se tratando de testemunho infantil, também já se atenta à falta de cuidado nas entrevistas realizadas ao longo de toda a persecução penal - englobando tanto a fase investigativa quanto a judicial, assim expressado na Apelação Crime nº 70050611151 , da Primeira Câmara Criminal:

Infelizmente, no mais das vezes, diante de inúmeros depoimentos e entrevistas sem o devido cuidado, a criança acaba incorporando em seu relato a respeito de fatos concretos informações sugeridas pela situação gerada nos próprios depoimentos e/ou dados sugeridos por adultos que com elas trataram sobre o assunto e/ou, ainda, dados simplesmente fantasiosos ${ }^{25}$.

Quanto à submissão do entrevistado à avaliação pericial de cunho psicológico ou psiquiátrico, verificou-se que em $65,45 \%$ dos casos foi realizada perícia para atestar a veracidade das declarações tomadas, dos quais $34,55 \%$ mencionaram que o exame contou com quesito específico acerca da presença ou não de falsas memórias na narrativa, enquanto $30,91 \%$ apenas aferiram sobre a credibilidade do testemunho.

Aliás, salienta-se que todas as avaliações se deram sobre a palavra da vítima, criança e adolescente, no contexto de delitos contra a dignidade sexual. E que, embora, aproximadamente, metade delas tenha trazido expressamente a análise sobre a criação ou não de falsas memórias, o objetivo primordial dessas perícias era constatar a veracidade das narrativas sobre a ocorrência ou não de abuso, e não propriamente o processo mnemônico do falseamento da memória - não obstante esteja, na grande parte, implícito.

25 RIO GRANDE DO SUL. Tribunal de Justiça. Apelação Crime $N^{\circ} 70050611151$, da $1^{\text {a }}$ Câmara Criminal. Apelante: Ministério Público. Apelado: Wilson Pelufe de Carvalho. Relator: Des. Sylvio Baptista Neto. Porto Alegre, 12 de dezembro de 2012 . 
A fim de elucidar o ponto, colaciona-se um exemplo em que a perícia adotada como razão de decidir avaliou expressamente a presença de falsas memórias no relato da vítima e outro em que somente atestou a veracidade do depoimento, respectivamente:

Por outro lado, insta salientar que a perita médico-legal psiquiatra, após tomar o relato da vítima-periciada, consignou que 'a periciada não apresenta limitação alguma de ordem psicológica ou limitação em suas capacidades cognitivas que a impeçam de emitir um relato válido', assim como que 'A possibilidade de falsas memórias neste contexto se torna muito remota', sendo que, ao final, concluiu que 'A periciada apresenta sofrimento psíquico decorrente da situação relatada. As alterações emocionais e comportamentais apresentadas pela periciada, em conjunto com a declaração emitida, são compatíveis e reforçam a hipótese de abuso sexual intra familiar. ${ }^{26}$. (grifo do autor).

De ressaltar, igualmente, as conclusões esposadas pelo perito médico-legal no sentido de S. O. B. apresentar 'limitação de ordem neuropsíquica por prejuízo de suas capacidades cognitivas decorrentes de retardo mental [...] moderado', revelando-se provável que as informações básicas então fornecidas pela mesma correspondam 'a recordações realmente vivenciadas' (fls. 201-205) ${ }^{27}$.

Vê-se, com isso, que o tema ainda não é quesito específico de costume nas avaliações periciais realizadas para se atestar a veracidade ou não da palavra da vítima ou da testemunha. Observou-se, ainda, das 19 decisões que destacaram ter havido a abordagem expressa das falsas memórias nas perícias psicológicas ou psiquiátricas realizadas, que em dois casos foi aplicada a técnica da entrevista cognitiva aprimorada ${ }^{28}$.

26 RIO GRANDE DO SUL. Tribunal de Justiça. Apelação Crime $N^{\circ} 70064554017$, da $6^{\mathrm{a}}$ Câmara Criminal. Apelante: E.S.L. Apelado: Ministério Público. Relatora: Des. ${ }^{a}$ Vanderlei Teresinha Tremeia Kubiak. Porto Alegre, 11 de dezembro de 2015.

27 RIO GRANDE DO SUL. Tribunal de Justiça. Apelação Crime $N^{\circ} 70053638847$, da $7^{a}$ Câmara Criminal. Apelante: P. Apelado: Ministério Público. Relatora: Des. ${ }^{a}$ Naele Ochoa Piazzeta. Porto Alegre, 29 de abril de 2014.

28 A técnica da Entrevista Cognitiva é uma das mais eficazes para gerar sugestionabilidades em questionamentos. Têm sido utilizada há mais de 20 anos em países como o Reindo Unido no aprimoramento das entrevistas forenses. RIO GRANDE DO SUL. Tribunal de Justiça. Apelação Crime $N^{o}$ 
Ademais, 34,55\% do total das decisões analisadas não mencionaram ter havido a submissão da pessoa cujo relato teve sua credibilidade questionada ao exame técnico psicológico/psiquiátrico.

Traçado esse caminho, adentrou-se, então, na análise acerca da forma como o fenômeno das falsas memórias vem sendo percebido pelo TJRS e como tem repercutido no resultado do processo. Verificou-se que em todos os casos a prova cuja credibilidade foi questionada em razão da possibilidade da produção de falsas memórias foi o principal meio probatório utilizado para a formação do convencimento dos julgadores, tanto para um juízo de condenação (92,73\%), como de pronúncia (1,82\%), como de absolvição (5,45\%).

Ao se buscar uma análise sobre como vem sendo realizada a fundamentação nos acórdãos para o reconhecimento ou não das falsas memórias, estabeleceram-se alguns critérios com vistas ao artigo 93, inciso IX, da Constituição Federal ${ }^{29}$ : consideraram-se como detalhadamente fundamentadas as decisões judiciais que discorreram sobre o tema com base na literatura científica, bem como aquelas que adotaram o resultado das perícias psicológicas/psiquiátricas realizadas nos autos como razões de decidir. Por outro lado, entendeu-se que houve uma análise superficial do tema quando o voto se limitou a afastar ou reconhecer as falsas memórias, sem a realização de laudo pericial ou embasamento científico sobre a temática, assim como quando se deteve à análise da prova oral carreada ao processo e à credibilidade do depoimento/testemunho, sem, contudo, abordar expressamente o falseamento da memória - nesses

70061654463, da $8^{\text {a }}$ Câmara Criminal. Apelante: L.M.M. Apelado: Ministério Público. Relatora: Des. ${ }^{a}$ Fabianne Breton Baisch. Porto Alegre, 11 de maio de 2016.; RIO GRANDE DO SUL. Tribunal de Justiça. Apelação Crime $N^{o}$ 70058885583, da 8 ${ }^{\mathrm{a}}$ Câmara Criminal. Apelante/Apelado: Ministério Público. Apelante/Apelado: V.F.G. Relatora: Des. ${ }^{a}$ Bernadete Coutinho Friedrich. Porto Alegre, 28 de maio de 2015.

“CF, Art. 93. Lei complementar, de iniciativa do Supremo Tribunal Federal, disporá sobre o Estatuto da Magistratura, observados os seguintes princípios: [...] IX todos os julgamentos dos órgãos do Poder Judiciário serão públicos, e fundamentadas todas as decisões, sob pena de nulidade, podendo a lei limitar a presença, em determinados atos, às próprias partes e a seus advogados, ou somente a estes, em casos nos quais a preservação do direito à intimidade do interessado no sigilo não prejudique o interesse público à informação; (Redação dada pela Emenda Constitucional n 45, de 2004)”. 
casos, a expressão veio contida na síntese das razões recursais defensivas dispostas no relatório do acórdão.

A fim de ilustrar esses critérios, colacionam-se os exemplos a seguir:

\section{A) ABORDAGEM DETALHADA DO TEMA:}

Em processo relacionado ao delito de tráfico de drogas, a defesa suscitou contradição entre os depoimentos dos policiais militares responsáveis pela prisão em flagrante dos réus. Em análise da ausência ou não de homogeneidade em pontos periféricos do teor dos depoimentos questionados, foram abordados vários fatores, como visão, atenção, percepção, memória, comunicação e redação do depoimento. A expressão "falsas memórias" foi mencionada quando da abordagem do fator "memória" da testemunha, consoante se depreende de trecho do voto de lavra da Desembargadora Relatora Osnilda Pisa, proferido na Apelação Crime $\mathrm{n}^{\circ}$ 70036509917, da Segunda Câmara Criminal:

Trata-se, pois, de falta de homogeneidade, em pontos periféricos, nos relatos dos policiais sobre a dinâmica dos fatos. Contudo, isso longe está de caracterizar contradições capazes de fragilizar o acervo probatório. Ao contrário, demonstra que não se trata de versões preparadas. Além disso, a ausência de homogeneidade em pontos periféricos do teor dos depoimentos consignados decorre de vários fatores:

(a) visão: cada um dos três policiais visualizou o atuar do réu de um lugar diferente. Não podemos esquecer que eles se encontravam em policiamento motorizado e, evidentemente, a posição dentro da viatura afetou a visão que cada um (motorista, caroneiro sentando ao lado do motorista e no banco traseiro);

(b) atenção: a atenção dos três policiais poderia estar focada em pontos diversos. Das versões apresentadas por ocasião da lavratura do auto de prisão em flagrante (fls. 27/30), quando os eventos visualizados se encontravam mais vívidos na memória, percebe-se que os policiais, inicialmente focaram sua atenção no corréu Ralf:

$[\ldots]$ 
c) percepção (ou apercepção): além da realidade vista (fatos externos), agrega valores e vivências individuais (fatos internos), como, por exemplo, concluir que os dois denunciados estavam conversando simplesmente porque estavam próximos, ainda que a testemunha não tenha ouvido o teor da conversa ou visualizado efetivamente os dois conversando.

(d) memória: depende da capacidade de cada testemunha para fixar, conservar, reconhecer e evocar (lembrar) os acontecimentos. Nesse processo, detalhes são esquecidos, outros alterados e, ainda, alguns acrescentados. É o caso das falsas memórias. São lembranças que não correspondem ao acontecimento, informação que não guarda fidelidade ao original. No caso dos policiais militares, que atuam em equipe, acabam reunindo as informações de cada um, os detalhes que cada um presenciou, de modo a formarem um relato da dinâmica do evento na sua integralidade. E, muitas vezes, ao evocarem a memória do fato testemunhado, recordam de detalhes inicialmente relatados por um colega e não necessariamente presenciados.

(e) comunicação: A forma como a testemunha transmite a narrativa do acontecimento. Algumas testemunhas são prolixas e outras, extremamente concisas no relator acontecimentos.

(f) redação do depoimento (art. 215 do CPP). Em que pese a orientação legal, exceto quando o depoimento é gravado (ainda assim aparecem falhas da degravação, especialmente quanto à pontuação, que pode alterar completamente o sentido de uma frase), sabe-se o quanto é difícil, na redação do depoimento, o inquiridor, cingirse, tanto quanto possível, às expressões usadas pelas testemunhas, reproduzindo fielmente as suas frases.

Com essas informações, é possível compreender a origem da falta de homogeneidade entre os depoimentos consignados na repartição policial e em juízo, e entre os depoimentos das testemunhas sob o crivo do contraditório. Por ocasião da lavratura do auto de prisão em flagrante, os detalhes estão mais vívidos na memória das testemunhas, mas a forma de inquirição da testemunha e de redigir o depoimento, por si só, acaba interferindo no conteúdo do termo de declarações e, muitas vezes, afetando a própria memória da testemunha. 
Vejamos, então, os relatos das testemunhas apresentados em juízo, quase três meses depois do evento e, provavelmente, com atendimento de várias outras ocorrências similares, situação que também pode interferir na memória do evento:

$[\ldots]$

Por conseguinte, muito embora toda a gama de fatores que influenciam a redação final do depoimento das testemunhas, no caso, não há contradições ${ }^{30}$. (grifo do autor).

Em processo relacionado ao delito de estupro de vulnerável, a defesa postulou o reconhecimento de falsas memórias no relato da vítima com 09 anos de idade à época do fato. A decisão, além de afastar a tese defensiva com base na literatura nacional, trouxe interessante entendimento, no sentido de que cabia à defesa postular a realização de perícia psiquiátrica com a inclusão de quesito específico para tanto. Esse entendimento não restou isolado no conjunto das decisões analisadas, como adiante se abordará. A Desembargadora Relatora Naele Ochoa Piazzeta, em voto proferido na Apelação Crime no 70070854104 , da Oitava Câmara Criminal, trouxe excertos de literatura que trata do tema das falsas memórias:

Cumpre examinar a argumentação defensiva no sentido de que as declarações do ofendido estariam impregnadas de falsas memórias, estas provenientes de traumas ocasionados pelo modo autoritário como o acusado criou o infante, o que igualmente cumpriria por afastar o seu valor como meio de prova válido à condenação.

Com efeito, por falsas memórias entende-se os registros mnemônicos de determinado evento como sendo verdadeiros, quando, em realidade, jamais teriam ocorrido, comportando trazer à colação os ensinamentos de Jorge Trindade ${ }^{5}$ acerca do tema, com o que evito tautologia:

“[...]

30 RIO GRANDE DO SUL. Tribunal de Justiça. Apelação Crime $N^{0} 70036509917$, da $2^{\text {a }}$ Câmara Criminal. Apelante: Fabio Machado Alves. Apelado: Ministério Público. Relatora: Des. ${ }^{a}$ Osnilda Pisa. Porto Alegre, 22 de abril de 2012. 
As declarações, sejam elas fornecidas por crianças ou adultos, podem ser consideradas verdadeiras ou falsas. Quando falsas, a desconformidade pode decorrer tanto de fatores externos (exógenos) - também denominados ecológicos -, quanto de fatores internos (endógenos). Do ponto de vista estritamente psicológico, elas podem apresentar um elemento motivacional deliberado e proposital (mentira) ou não (falsas memórias).

Nesse aspecto, a falsa memória, como conjunto de características que compõe uma síndrome, é referida, em geral, como uma evocação mnêmica relativa a fato não acontecido (fato inexistente, em relação ao qual a mente está in albis), mas ela também pode se apresentar como uma distorção perceptiva na qual a recordação ou sua evocação recai sobre fato existente, modificado por refrações da realidade, isto é, uma memória configurada de maneira parcialmente equivocada (memórias distorcidas), em qualquer das hipóteses, geradas pelo próprio sujeito ou implantadas por outrem, mas para ele tidas e havidas como reais e verdadeiras.

[...]" (TRINDADE, Jorge; BREIER, Ricardo. Pedofilia: aspectos psicológicos e penais. $2^{\mathrm{a}}$ edição. Porto Alegre: Livraria do Advogado, 2010. p. 58).

Do exposto, reafirmo ser inegável a ocorrência dos fatos descritos na incoativa, manifesta a validade dos relatos do vulnerável, estes avigorados pelas declarações das demais testemunhas ouvidas em pretório e pelo parecer psicológico encartado às fls. 35-36, não passando, a tentativa da desqualificá-los, de vertente carecedora de credibilidade.

É dizer, nada foi produzido no sentido de comprovar que eventuais traumas pretéritos - decorrentes da forma arbitrária como o pai criou o filho - tenham influenciado nos processos de memorização e de esquecimento do infante.

Friso, porque adequado, que novamente aqui cabia à defesa postular a realização de perícia psiquiátrica, com a elaboração de quesitos onde a questão poderia ser devidamente trabalhada, sendo que, ao deixar o tema passar incólume durante a instrução, 
não se revela capaz, agora, em sede recursal, de incutir dúvida passível de acolher a pretensão absolutória embasada em alegadas falsas lembranças ${ }^{31}$.

Consoante referido, os casos em que a formação de falsas memórias foi objeto de quesito específico na perícia realizada para constatar a credibilidade do relato, em que pese não ter havido uma maior aproximação quanto aos conceitos e peculiaridades desse fenômeno, consideraram-se atendidos os requisitos do artigo 93, inciso IX, da Constituição Federal quanto à temática.

A elucidar, cita-se a decisão proferida no julgamento da Apelação Crime $\mathrm{n}^{\mathrm{o}} 70053602108$, na qual o relator destacou o resultado da prova técnica para afastar a ocorrência de falsas memórias. No caso concreto, o laudo de avaliação psiquiátrica confirmou a coerência da narrativa da ofendida e ressaltou ser remota a possibilidade de falsas memórias naquele contexto, pois se tratava "[...] de mais de um episódio recordado e a periciada teria de criar uma falsa memória para cada episódio. Além disso, pouco tempo transcorreu entre os fatos e o presente exame, o que reduz a possibilidade de haver distorções na memória da vítima ${ }^{32}$ ".

\section{B) ABORDAGEM NÃO DETALHADA DO TEMA:}

O que se percebeu dos julgados em que não houve uma análise mais aprofundada sobre o fenômeno das falsas memórias é que há um exame sobre o depoimento das vítimas e das testemunhas que presenciaram os fatos com base nos próprios relatos que se encontram nos autos. Faz-se, por vezes, uma relação entre o relato prestado na fase policial e na fase judicial e, em não havendo discrepâncias ou existindo divergências em detalhes considerados irrisórios, resta afastada a ocorrência

31 RIO GRANDE DO SUL. Tribunal de Justiça. Apelação Crime $N^{\circ} 70070854104$, da $8^{\text {a }}$ Câmara Criminal. Apelante: E.P.K.. Apelado: Ministério Público. Relatora: Des. ${ }^{a}$ Naele Ochoa Piazzeta. Porto Alegre, 30 de novembro de 2016.

RIO GRANDE DO SUL. Tribunal de Justiça. Apelação Crime $N^{0} 70053602108$, da $7^{\text {a }}$ Câmara Criminal. Apelante: D.D.M. Apelado: Ministério Público. Relator: Des. José Conrado Kurtz de Souza. Porto Alegre, 20 de junho de 2013. 
de falsas memórias. É o caso da Apelação Crime nº 70063302889, da Sexta Câmara Criminal:

O relato fornecido pela vítima é deveras concreto e coeso, não transparecendo que seja fruto de falsas memórias, porventura oriundas de algum trauma de violência sofrido imediatamente após o término da carona que lhe foi dada. Outrossim, a narrativa fornecida em juízo converge com o seu depoimento colhido na fase investigatória, ainda no Hospital de Pronto Socorro desta Capital, nosocômio em que foi atendida e onde há posto da Polícia Civil (fl. 08) ${ }^{33}$.

Em sentido semelhante, foi o voto extraído da Apelação Crime $\mathrm{n}^{\circ}$ 70066114307, no qual, após ser analisada a palavra da vítima, apenas referiu que nada havia no processo a indicar a ocorrência de falsas memórias $^{34}$. Igualmente, na Apelação Crime n ${ }^{0} 70060770138$, foi destacado que não existia nenhuma circunstância no fato que fizesse crer que a vítima, “[...] menor impúbere, desprovida de libido [...]", tivesse fantasiado o abuso sexual ou que nela tivessem sido incutidas falsas memórias ${ }^{35}$.

De outra banda, não obstante tenham alguns acórdãos se debruçado sobre o exame pormenorizado da prova angariada no processo, conferindo credibilidade ou não ao relato sobre o qual havia sido suscitada a ocorrência de falsas memórias pela defesa, não foi abordado expressamente esse fenômeno mnemônico. É o que se depreende da Apelação Criminal $\mathrm{n}^{0} 70052292844^{36}$.

33 RIO GRANDE DO SUL. Tribunal de Justiça. Apelação Crime No 70063302889 , da $6^{a}$ Câmara Criminal. Apelantes: Willian Bittencourt da Silva e Valdecir Daniel Cabral de Miranda. Apelado: Ministério Público. Relatora: Des. ${ }^{a}$ Bernardete Coutinho Friedrich. Porto Alegre, 10 de dezembro de 2015. RIO GRANDE DO SUL. Tribunal de Justiça. Apelação Crime $N^{\circ} 70066114307$, da $8^{\text {a }}$ Câmara Criminal. Apelante: Gilson Hegner. Apelado: Ministério Público. Relatora: Des. ${ }^{a}$ Fabianne Breton Baisch. Porto Alegre, 26 de abril de 2017. RIO GRANDE DO SUL. Tribunal de Justiça. Apelação Crime $N^{\circ} 70060770138$, da $6^{\mathrm{a}}$ Câmara Criminal. Apelante/Apelado: Ministério Público. Apelante/ Apelado: J.A.F. Relatora: Des. ${ }^{a}$ Bernardete Coutinho Friedrich. Porto Alegre, 11 de junho de 2015.

36 RIO GRANDE DO SUL. Tribunal de Justiça. Apelação Crime $N^{\circ} 70052292844$, da $6^{\text {a }}$ Câmara Criminal. Apelante: A.S.L.. Apelado: Ministério Público. Relatora: Des. ${ }^{a}$ Bernardete Coutinho Friedrich. Porto Alegre, 08 de maio de 2014. 


\section{c) RESULTADO DA PESQUISA}

A partir de tais critérios pode-se afirmar que em $50,91 \%$ de casos, ou seja, 28 decisões, abordagem do tema das falsas memórias foi realizada de forma detalhada, enquanto em 49,09\% de casos, ou 27 decisões, isso foi feito de forma superficial, conforme demonstrado no Gráfico 3.

GráfIco 3 - Produção de Acórdãos no Período da Pesquisa

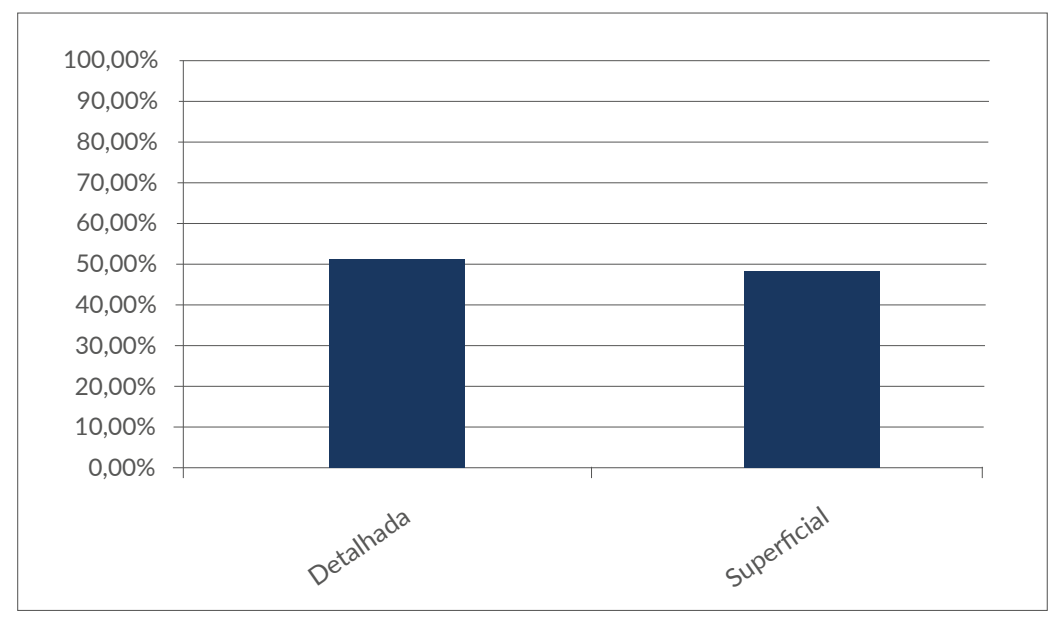

Fonte: Os autores.

Tangente ao reconhecimento de falsas memórias, os números são expressivos: em 92,73\% dos casos, ou seja, em 51 decisões analisadas foi afastada a hipótese - aqui também considerados os casos em que foi conferida credibilidade ao testemunho; enquanto em 1,82\% dos casos, ou seja, em apenas 01 decisão foi reconhecida a presença do fenômeno mnemônico no relato. Ainda, em 3,64\% dos casos, ou seja, em apenas 02 decisões não foi afastada a credibilidade do testemunho, porém também não foi descartada a hipótese de ocorrência de falsas memórias. Por fim, na decisão proferida em Recurso em Sentido Estrito, que representou $1,82 \%$ dos julgados apreciados, embora suscitado pela defesa, o acórdão sequer analisou a credibilidade da prova testemunhal. É o que apresenta o Gráfico 4. 
GRÁFIco 4 - Repercussão das Falsas Memórias

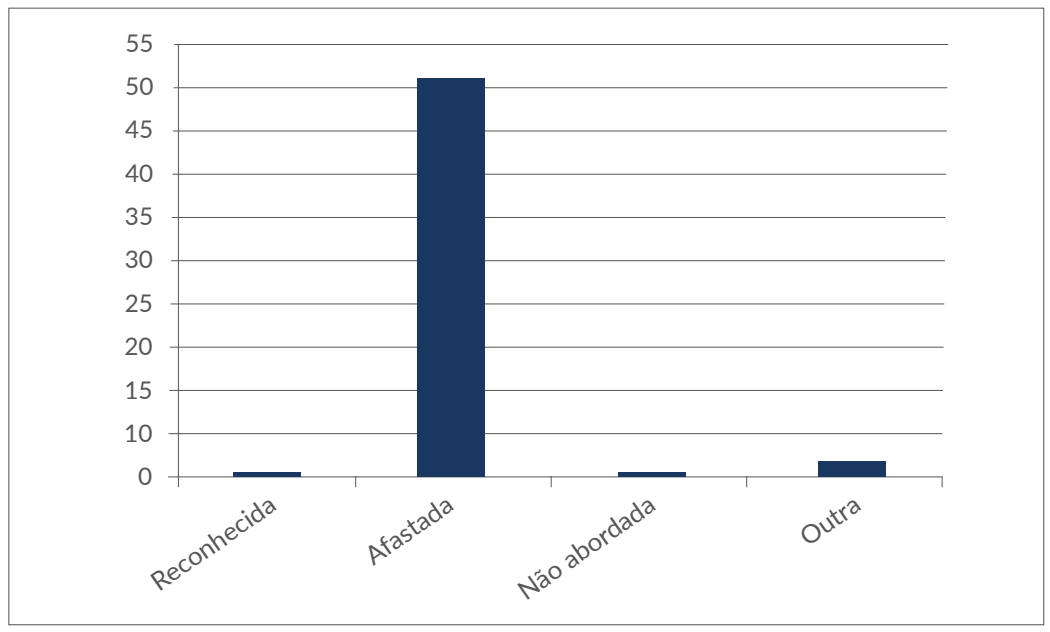

Fonte: Os autores.

O único acórdão que reconheceu a ocorrência de falsas memórias estava relacionado ao delito de atentado violento ao pudor anterior à alteração legislativa que revogou o artigo 214 do Código Penal. Na ocasião, entendeu-se que o transcurso do tempo entre a data dos fatos e a data do relato judicial da vítima, tomado pelo Sistema do Depoimento Sem Dano, deu ensejo à criação de falsas memórias. Segue trecho do voto emanado da Apelação Crime nº 70064804115 :

Assiste razão à defesa.

Inicialmente, esclareço que o fato narrado na denúncia aconteceu no dia 19.11.2003, quando a vítima contava com dois anos de idade. Ocorre que ela somente foi ouvida em 03.08.2010, quando já contava com nove anos de idade, por meio da sistemática do depoimento sem dano. Ressalto que não consta dos autos qualquer oitiva da vítima em momento anterior, seja por psicólogos, conselheiros tutelares ou por outros profissionais da área. Considerando a idade da vítima à época do fato, evidente que os relatos que fez em juízo, com nove anos de idade, tratam-se de falsas memórias, 
criadas, possivelmente, com base em relatos que lhe foram feitos pelos familiares (fls. 84-85v) ${ }^{37}$. (grifo nosso).

Ainda nessa perspectiva tempo-memória, mesmo que trate de testemunho infantil, interessante destacar mais uma vez a decisão proferida na Apelação Crime $\mathrm{n}^{0}$ 70060770138, supracitada, que, ao apreciar a tese defensiva de nulidade do depoimento da vítima colhido através de produção antecipada de prova, entendeu ser o decurso do tempo motivo suficiente para a urgência da coleta da prova oral ${ }^{38}$.

\section{II) Ilegalidade da produção de prova antecipada}

O fato ocorreu em novembro de 2008 , quando a vítima possuía apenas oito anos de idade. Depois de recebida a denúncia, houve dificuldade em se apurar a localização do réu, havendo transcorrido mais de um ano sem que fosse citado. Por isso, o Ministério Público, em junho de 2010, postulou a produção antecipada de prova, consistente no depoimento da vítima, considerada a ausência de outra fonte probatória acerca do fato delituoso, bem como a efemeridade da memória infantil, principalmente em se tratando de episódio traumático.

Com efeito, a cautela por parte do Ministério Público se mostrava deveras razoável, já que não havia como, no exercício de futurologia, prever quando o réu seria encontrado e citado, e quando dar-se-ia a instrução processual, o que evidenciava a urgência na colheita do depoimento.

Outrossim, o devido processo legal restou observado, havendo a Defensoria Pública intervindo na produção da prova, cujo

37 RIO GRANDE DO SUL. Tribunal de Justiça. Apelação Crime $N^{0} 70064804115$, da $7^{\text {a }}$ Câmara Criminal. Apelante: A.T.C.S. Apelado: Ministério Público. Relator: Des. Carlos Alberto Etcheverry. Porto Alegre, 09 de junho de 2016. O tempo atua de forma determinante para a diminuição da nitidez da memória, inclusive em termos de detalhes a serem lembrados pela testemunha. Esta questão pode impactar determinantemente na realização da prova, necessitando-se estudar os possíveis impactos deste fator ao processo penal. Neste sentido: ALTOE, Rafael; ÁVILA, Gustavo Noronha de. Aspectos cognitivos da memória e a antecipação da prova testemunhal no processo penal. Revista Opinião Jurídica, v. 20, p. 255-270, 2017. 
contraditório não foi repelido, mas tão somente diferido, inexistindo nulidade de qualquer espécie. ${ }^{39}$.

Contudo, cumpre dizer que os entendimentos supracitados restaram praticamente isolados diante das demais decisões analisadas. Isso porque o que se observou nos julgados é o entendimento de que o transcurso do tempo entre o relato prestado na fase da investigação e aquele prestado na fase judicial tanto pela vítima como pela testemunha, justificaria as discrepâncias entre as narrativas, e que em razão disso eventuais inconexões de detalhes seriam aceitáveis.

Em que pese seja cediço na literatura científica que o lapso temporal entre a data da aquisição e a da evocação da memória interfere no processo mnemônico, podendo contaminá-lo e dar ensejo a falsas memórias, esse fator, na maioria das vezes, não foi considerado negativamente na apreciação da prova oral. O entendimento que se extrai dos julgados é no sentido de que, se as declarações da vítima se mantêm íntegras, eventuais discrepâncias adviriam do tempo transcorrido entre a data do fato e a audiência de instrução e julgamento ${ }^{40}$.

Seguindo-se às duas decisões nas quais não foi afastada a credibilidade do testemunho, mas também não foi descartada a hipótese de ocorrência de falsas memórias, ambas também foram lançadas em processos relacionados a delitos contra a dignidade sexual de crianças. Além disso, o sugestionamento externo pelos familiares foi considerado como possível fator de contaminação da palavra das ofendidas nos dois casos.

O julgador que proferiu o voto na Apelação Crime no 70054703061 convenceu-se de que não existiam subsídios no processo que pudessem dar credibilidade à palavra da vítima. Em que pese não tenha sido questionada a veracidade do relato da vítima, entendeu-se que o laudo pericial

39 RIO GRANDE DO SUL. Tribunal de Justiça. Apelação Crime No 70060770138 , da $6^{\mathrm{a}}$ Câmara Criminal. Apelante/Apelado: Ministério Público. Apelante/

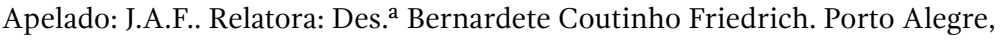
11 de junho de 2015.

40 RIO GRANDE DO SUL. Tribunal de Justiça. Apelação Crime $N^{\circ} 70041511668$, da $7^{\mathrm{a}}$ Câmara Criminal. Apelante: E. C. L. Apelado: Ministério Público. Relator: Des. José Conrado Kurtz de Souza. Porto Alegre, 14 de abril de 2011. 
era “[...] dúbio e contraditório, não fornecendo elementos concretos o bastante para a formação de um juízo de certeza acerca do fato denunciado". Logo, a decisão foi no sentido de que não se podia desprezar completamente a possibilidade de que tivesse havido alguma influência externa na formação do relato da vítima ou mesmo se tratar de falsas memórias $^{41}$, resultando absolvido o acusado.

No mesmo sentido, foi o julgamento da Apelação n ${ }^{\circ} 70037037637$, no qual o julgador entendeu que, embora não parecesse ser caso de implantação de falsas memórias na vítima, tudo indicava que a acusação havia sido fruto de "[...] uma grande e louvável preocupação da avó da menina, ao flagrá-la manipulando os órgãos genitais, bem como da própria mãe da criança $[\ldots] "$ ". 2 .

Por fim, atenta-se, ainda, para o posicionamento manifestado em alguns julgados no sentido de ser da defesa o ônus de provar a contaminação do testemunho pela presença de falsas memórias, cabendo ao réu "[...] postular a realização de perícia psiquiátrica, com a elaboração de quesitos onde a questão poderia ser devidamente trabalhada [...]". Inexistindo tal requerimento durante a instrução, restou afastada a possibilidade de se discutir, em sede recursal, “[...] a pretensão absolutória embasada em alegadas falsas lembranças" ${ }^{43}$.

\section{Considerações Finais}

Os dados apontaram que, na grande maioria dos julgados, a tese de falsas memórias foi afastada. No único acórdão em que foi expressamente reconhecida, se tratava da palavra da vítima e o fator de contaminação

41 RIO GRANDE DO SUL. Tribunal de Justiça. Apelação Crime $N^{\circ} 70054703061$, da $6^{\mathrm{a}}$ Câmara Criminal. Apelante: L.F.R. Apelado: Ministério Público. Relator: Des. Ícaro Carvalho de Bem Osório. Porto Alegre, 14 de novembro de 2013.

42 RIO GRANDE DO SUL. Tribunal de Justiça. Apelação Crime $N^{\circ} 70037037637$, da $6^{\mathrm{a}}$ Câmara Criminal. Apelante: Ministério Público. Apelado: S.R.P. Relatora: Des. ${ }^{\text {a }}$ Fabianne Breton Baisch. Porto Alegre, 11 de abril de 2012.

43 RIO GRANDE DO SUL. Tribunal de Justiça. Apelação Crime No 70073242539 , da $8^{a}$ Câmara Criminal. Apelante: Rafael Santos de Lima. Apelado: Ministério Público. Relatora: Des. ${ }^{a}$ Naele Ochoa Piazzeta. Porto Alegre, 10 de maio de 2017. 
apontado foi o transcurso do tempo entre a data do fato e a do relato tomado em juízo, sem qualquer análise psicológica/psiquiátrica.

Em que pese alguns acórdãos já tragam uma preocupação maior com a problemática das falsas memórias no testemunho, os resultados demonstram ainda haver um distanciamento dos atores jurídicos sobre a compreensão do tema e da complexidade que o envolve.

A prova testemunhal constitui-se em elemento de convicção fundamental na formação do convencimento do julgador. Independente do delito cometido e da forma como foram tomadas as declarações das testemunhas e, também, das vítimas, a situação com a qual se depara o magistrado, na maioria dos casos, é a de que o processo penal está instruído basicamente com a prova oral. O juízo final, assim, fica submetido essencialmente à palavra de pessoas que tenham presenciado ou vivenciado o fato delituoso, que se substancia, geralmente, em um evento traumático.

A análise desse conjunto probatório costuma ser realizada sob um pensamento binário pelos atores judiciais, típico de um pensar isolado do Direito, sem uma visão interdisciplinar com outras áreas do saber: no testemunho, ou se está dizendo a verdade ou se está mentindo. E mais do que isto, se o indivíduo não possui motivos para mentir ou imputar falsamente a um terceiro desconhecido a prática de um crime, estará, então, falando "a" verdade.

Dentro desse contexto, o tempo transcorrido entre a data do fato e os depoimentos colhidos será irrelevante; o ambiente criado para a oitiva da testemunha e a técnica empregada na realização da entrevista não importarão. Tampouco se a tomada das declarações foi presidida por um julgador parcial que, extrapolando as funções que lhe cabem em um modelo processual acusatório, busca confirmar a versão trazida na denúncia.

Se o caso é de grande repercussão e a mídia tiver feito questão de manter toda a população informada acerca de cada passo das investigações, melhor: o que foi presenciado jamais cairá no esquecimento. Descartada a hipótese de estar a testemunha ou a vítima mentindo, é conferida credibilidade às suas declarações, sendo suficientes a embasar um édito condenatório.

Não se vê prejuízo ao réu, afasta-se a nulidade do ato procedido em desacordo com as formalidades legais, pois crível é o testemunho evocado em juízo que se manteve idêntico ao relato prestado na fase 
policial. Até porque, se os diversos depoimentos tomados ao longo de toda a persecução criminal, mesmo que sem qualquer cuidado, não estiverem em consonância, duvidosa é a testemunha e desacreditada será.

Ocorre que entre a verdade e a mentira, há um mar de possibilidades implicados na memória humana. Há, especialmente, as falsas memórias. O cenário que se encontra no cotidiano forense ignora que a prova oral está intimamente ligada a um complexo processo mnemônico, que depende de fatores que vão além da boa-fé ou da má-fé das pessoas.

Inclusive, surpreendem os experimentos científicos sobre a memória humana. Mais surpreendentes ainda são aqueles que tratam da criação de falsas memórias. Quando se faz um paralelo entre o contexto criado nas experiências laboratoriais e o processo penal, os resultados chegam a ser assustadores.

Desde o início da formação da memória e, consequentemente, do testemunho, que ocorre com o presenciar dos fatos, as recordações já podem estar suscetíveis a falhas. Isso porque a aquisição de uma lembrança deve ocorrer de forma atenta e consciente.

Embora não seja a solução de todos os problemas, além de ainda se mostrar distante da realidade forense, pelo tempo que demanda o atendimento de todos os passos da referida técnica, acredita-se que ao menos a capacitação dos atores jurídicos para a formulação de questionamentos apropriados, com perguntas abertas, já poderia exercer um resultado positivo sobre a coleta da prova oral, evitando-se, assim, tamanha exposição da testemunha às sugestionabilidades do entrevistador.

Ademais, a falta de cuidado com a oitiva das testemunhas, para a qual a literatura sobre a psicologia do testemunho chama a atenção, é facilmente identificada na prática. Da leitura dos acórdãos objeto de análise no terceiro capítulo, pode-se observar um distanciamento com a temática. Percebe-se, inclusive, uma falta de conhecimento acerca do tema e da complexidade que o envolve.

Não obstante a problemática das falsas memórias seja suscitada nos acórdãos com certa familiaridade, considerando o vasto número de julgados que resultaram da pesquisa, o que se encontrou, em verdade, foi uma abordagem superficial do fenômeno, faltando compreensão sobre a sua extensão.

A começar pelo resultado quase ínfimo de decisões que tratavam da presença de falsas memórias em testemunho adulto, tendo a matéria sido 
trazida predominantemente sobre o testemunho infantil. Esses dados, além de confirmarem haver uma maior preocupação da comunidade jurídica com a memória da criança e do adolescente, reforçam a ideia de que o tema ainda é pouco difundido no âmbito acadêmico e profissional do Direito. Esse resultado ressalta, mais uma vez, a importância do presente estudo.

As decisões judiciais demonstraram, ainda, não haver uma preocupação com as técnicas de entrevista, nem com o ambiente criado para o acolhimento da testemunha ou da vítima, fundamentais para a obtenção de um relato com mais quantidade e qualidade de detalhes. Tais questões se mostraram quase irrelevantes quando analisada a credibilidade dos depoimentos. Até mesmo nos casos que tratavam do testemunho infantil.

Todavia, em todos os casos analisados, a prova cuja veracidade foi questionada teve papel fundamental na formação do convencimento dos julgadores, constituindo-se no elemento central de convicção. Além disso, na grande maioria dos acórdãos, a presença de falsas memórias na prova oral foi afastada, resultando em juízos condenatórios.

Em suma, o que se pode concluir da pesquisa é que, apesar de a tese da presença de falsas memórias na prova oral estar sendo frequentemente suscitada no âmbito recursal, o fenômeno não tem tido grande repercussão no resultado do processo, haja vista o número de decisões que o afastaram sem qualquer embasamento técnico científico que o tema exige.

O que se vê é a necessidade de se repensar a prova testemunhal como ato humano que é, dependente da memória maleável do homem e sujeita à falibilidade dos processos mnemônicos inerentes a cada indivíduo. E mais do que o melhoramento das técnicas de entrevista aplicadas às oitivas, com implementações de ordem legal, que demandariam grandes movimentos no aprimoramento do processo penal, fundamental que, primeiramente, se tome ciência da complexidade do tema das falsas memórias inseridas no seio do testemunho.

Não basta que a lei trate da matéria. Se isso fosse suficiente para se tomar consciência a respeito de temáticas tão importantes ao processo penal, que podem culminar na restrição de um direito fundamental do cidadão tal qual é a liberdade, não se teria ainda hoje, passados nove anos da alteração legislativa que implantou o sistema de cross-examination no Código de Processo Penal, juízes presidindo a tomada de depoimento, como se num sistema presidencialista inquisitivo ainda estivessem. 
Essencial que se aproxime os atores jurídicos da problemática das falsas memórias, a fim de que ao menos se reflita acerca de seus efeitos na prova testemunhal e, consequentemente, na convicção dos juízes. Pequenas medidas decorrentes do simples acesso ao conhecimento, tal como a adoção de perguntas abertas nas entrevistas policiais e judiciais, já seria capaz de transformar o testemunho em um relato livre de sugestões.

De qualquer sorte, apesar de a prova testemunhal não ser imaculada, não se pode deixar de acreditar nesse meio probatório, caso contrário, o próprio homem seria desacreditado.

\section{ReferênCIAS Bibliográficas}

ALTOE, Rafael; ÁVILA, Gustavo Noronha de. Aspectos cognitivos da memória e a antecipação da prova testemunhal no processo penal. Revista Opinião Jurídica, v. 20, p. 255-270, 2017. https://doi.org/10.12662/2447-6641oj.v15i20.p255-270.2017 AQUINO, José Carlos G. Xavier de. A prova testemunhal no processo penal brasileiro. 4. ed. rev. e ampl. São Paulo: Juarez de Oliveira, 2002.

ÁVILA, Gustavo Noronha de. Falsas Memórias e Sistema Penal. Rio de Janeiro: Lumen Juris, 2013.

DI GESU, Cristina. Prova penal e falsas memórias. 2. ed. ampl. e rev. Porto Alegre: Livraria do Advogado, 2014.

FARINACCI, Prosperi. Tractatus Integer de Testibus, 1617. Disponível em <http:// reader.digitale-sammlungen.de/en/fs1/object/display/bsb10625696_00001. html>. Acesso em: 15 nov. 2017.

GAUER, Gustavo. Falsas memórias. In: OLIVEIRA, Alcyr Alves (Org.). Memória: cognição e comportamento. São Paulo: Casa do Psicólogo, 2007. Livro eletrônico. p. $165-183$.

LOFTUS, Elizabeth; PALMER, J.C. Reconstruction of automobile destruction: An example of the interaction between language and memory. Journal of Verbal Learning \& Verbal Behavior, vol. 13, n. 5, p. 585-589, 1974. https://doi.org/10.1016/ s0022-5371(74)80011-3

LOPES JÚNIOR, Aury. Direito processual penal. 11. ed. São Paulo: Saraiva, 2014.

NEUFEULD, Carmem; BRUST, Priscila Goergen; STEIN, Lilian Milnitsky. Compreendendo o fenômeno das falsas memórias. In: STEIN, Lilian Milnitsky et al. Falsas memórias: fundamentos científicos e suas aplicações clínicas e jurídicas. Porto Alegre: Artmed, 2010. p. 21-41. 
MORAIS DA ROSA, Alexandre. Guia Compacto do Processo Penal. $3^{\text {a }}$ ed. Florianópolis: Empório do Direito, 2016.

STEIN, Lilian Milnitsk (Org.). Falsas memórias: fundamentos científicos e suas aplicações clínicas e jurídicas. Porto Alegre: Artmed, 2010.

STEIN, Lilian Milnitsky; NEUFELD, Carmem Beatriz. Falsas Memórias: Porque Lembramos de Coisas que não Aconteceram? Arquivos de Ciências da Saúde da UNIPAR, vol. 5, n. 2, p. 179-186, 2001. https://doi.org/10.25110/arqsaude.v5i2.2001.1124

STEIN, Lilian Milnitsky; ÁVILA, Gustavo Noronha de et al. Avanços científicos em psicologia do testemunho aplicados ao reconhecimento pessoal e aos depoimentos forenses. Brasília, DF, 2015. Disponível em: <http://pensando.mj.gov.br/wp-content/uploads/2016/02/PoD_59_Lilian_web-1.pdf>. Acesso em: 03 set. 2017.

\section{Informações adicionais e declarações dos autores (integridade cientifica)}

Declaração de conflito de interesses (conflict of interest declaration): os autores confirmam que não há conflitos de interesse na realização das pesquisas expostas e na redação deste artigo.

Declaração de autoria e especificação das contribuições (declaration of authorship): todas e somente as pessoas que atendem os requisitos de autoria deste artigo estão listadas como autores; todos os coautores se responsabilizam integralmente por este trabalho em sua totalidade.

- Flaviane Baldasso: projeto e esboço inicial, coleta e análise de dados, levantamento bibliográfico, redação, aprovação da versão final.

- Gustavo Noronha de Ávila: projeto e esboço inicial, levantamento bibliográfico, revisão bibliográfica, redação, revisão crítica com contribuições substanciais, aprovação da versão final.

Declaração de ineditismo e originalidade (declaration of originality): os autores asseguram que o texto aqui publicado não foi divulgado anteriormente em outro meio e que futura republicação somente se realizará com a indicação expressa da referência desta publicação original; também atestam que não há plágio de terceiros ou autoplágio. 
Dados do processo editorial

(http://www.ibraspp.com.br/revista/index.php/RBDPP/about/editorialPolicies)

- Recebido em: 17/12/2017

- Controle preliminar e verificação de plágio: 19/12/2017

- Avaliação 1: 25/12/2017

- Avaliação 2: 04/01/2018

- Avaliação 3: 06/01/2018

- Avaliação 4: 07/01/2018

- Decisão editorial preliminar: 14/01/2018

- Retorno rodada de correções 1: 31/01/2018

- Decisão editorial preliminar 2: 31/01/2018

- Retorno rodada de correções 2: 05/02/2018

- Decisão editorial final: 05/02/2018

\section{Equipe editorial envolvida}

- Editor-chefe: 1 (VGV)

- Revisores: 4

\section{COMO CITAR ESTE ARTIGO:}

BALDASSO, Flaviane; ÁVILA, Gustavo N. A Repercussão do Fenômeno das Falsas Memórias na Prova Testemunhal: uma análise a partir dos Julgados do Tribunal de Justiça do Rio Grande do Sul. Revista Brasileira de Direito Processual Penal, Porto Alegre, vol. 4, n. 1, p. 371-409, jan./abr. 2018. https://doi.org/10.22197/rbdpp.v4i1.129

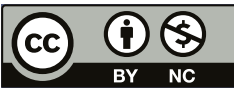

Esta obra está licenciada com uma Licença Creative Commons Atribuição-NãoComercial 4.0 Internacional. 